\title{
Penjadwalan Kompetisi Sepak Bola Liga PSN Ngada Menggunakan Algoritma Honey Bee Mating Optimization
}

\author{
Firdhansyah Abubekar ${ }^{\star 1}$, Yufis Azhar ${ }^{2}$, Agus Eko Minarno ${ }^{3}$ \\ 1,2,3 Teknik Informatika/Universitas Muhammadiyah Malang \\ firabubekar@gmail.com¹, yufis.az@gmail.com²
}

\begin{abstract}
Abstrak
Penjadwalan sepak bola menjadi salah satu factor kunci agar sebuah kompetisi yang diselenggarakan dapat berjalan baik atau tidak. Penjadwalan yang kurang baik akan mampu mempengaruhi kondisi tim yang akan bertanding, karena jadwal yang kurang baik akan menghambat tim untuk mempersiapkan timnya secara baik untuk pertandingan selanjutnya. Sehingga dalam penelitian ini akan merancang sistem yang dapat menentukan penajadwalan secara baik berdasarkan batasan masalah yang sebaiknya dihindari dalam menjadwalkan kompetisi sepak bola liga PSN Ngada fase 10 besar yang nmenggunakan sistem setengah kompetisi. Pada penelitian ini akan menggunakan algoritma honey bee mating optimization, algoritma ini dipilih karena mudah untuk diterapkan dan dapat menghasilkan penjadwalan yang cukup baik. Algoritma ini memungkinkan terbentuknya penjadwalan yang menghidari batasan yang telah ditentukan dari kombinasi yang telah dibentuk, yang telah melewati proses flight mating, crossover, mutasi dan pemilihan ratu. Siklus ini akan terus berlangsung hingga mencapai iterasi yang ditentukan dan memilih penjadwalan dengan nilai fitness terbaik.
\end{abstract}

Kata Kunci: Algoritma Genetika, Honey Bee Mating Optimization, Penjadwalan, Sepak Bola

\begin{abstract}
Soccer scheduling is one of the key factors so that the competition can be done well or not. Poor scheduling will affect the condition of the team that will compete, because a poor schedule will prevent the team from preparing their team well for the next match. For this research, we will discuss a system that can determine scheduling and also discuss issues that must be resolved in the big phase 10 PSN Ngada competition that uses a competition system. In this study, we will use the marriage honey bee optimization algorithm, this algorithm was chosen because it is easy to use and can produce quite good scheduling. This algorithm allows the formation of scheduling that avoids predetermined boundaries of combinations that have been formed, which have passed the process of mating flights, crossover, mutations and queen selection. This cycle will continue to run until it reaches the specified and choose scheduling with the best fitness value.
\end{abstract}

Keywords: Algorithm Genetic, Honey Bee Mating Optimization, Time Scheduling, Football

\section{Pendahuluan}

Liga PSN Ngada merupakan kompetisi yang menaungi klub-klub dari kabupaten Ngada, diikuti oleh 20 tim yang berasal dari 6 kecamatan berbeda. Seperti kompetisi lainnya masalah pada kompetisi liga PSN Ngada yaitu penjadwalan yang kurang optimimal dimana beberapa tim yang tidak mendapatkan jadwal istirahat yang sama atau tim yang berlokasi jauh dari stadion perlu dapat waktu khusus ketika bertanding dengan sesama tim yang jauh dari dari stadion [1]. Padahal penjadwalan yang baik akan sangat baik bagi kompetisi karena setiap tim dan panitia dapat mempersiapkan tim secara baik,penjadwalan yang buruk sudah sering terjadi baik dari kompetisi amatir sampai kompetsisi internasional didalam maupun luar negeri [2]. Pada penelitian ini akan menentukan jadwal pertandingan untuk fase 10 besar yang menggunakan fase setengah kompetisi, dimana setiap tim akan bertanding sebanyak 1 kali dengan tim lainnya.

Penelitian untuk kasus penjadwalan sudah sering diteliti oleh beberapa peneliti sebelumnya, baik pada penjadwalan mata pelajaran, penjadwalan piket, penjadwalan pengiriman barang dan lain lain. Untuk kasus penjadwalan algoritma First In First Out, Shortest Job First, Round Robin, dan Algoritma Genetika [3]. Algoritma genetika juga merupakan salah satu algoritma yang sering digunakan untuk mengatasi kasus penjadwalan, selain mudah diterapkan 
algoritma ini dapat memberikan hasil yang baik. Algoritma genetika merupakan jenis algoritma yang menirukan proses makhluk hidup dalam melakukan suatu aktivitas [4].

Algoritma honey bee mating optimization merupakan salah satu jenis dari algoritma genetika, algoritma honey bee mating optimization menirukan proses lebah dalam mencari ratu didalam populasi atau dalam kawanan, algoritma honey bee mating optimization ini mampu menangani masalah penjadwalan dengan baik karena cukup mudah untuk diterapkan dan dapat memberikan hasil yang baik ketika diterapkan pada kasus penjadwalan maupun untuk kasus lainnya [5].

Proses penjadwalan menggunakan algoritma honey bee mating optimization dimulai dengan membangkitkan jumlah individu atau populasi yang menjadi sekumpulan solusi yaitu berupa jadwal kompetisi secara lengkap yang diacak. Kemudian dilakukan penentuan ratu atau individu terbaik, proses flight mating, proses pembuahan/crossover, mutasi, dan juga penentuan ratu baru yang berdasarkan perbandingan nilai fitness dari ratu baru dan individu baru yang terbentuk [6].

Pada penelitiian ini akan menggunakan lebih banyak batasan/constraint dengan 7 constraint, dimana pada beberapa penelitian sebelumnya hanya menggunakan kurang lebih 3-4 batasan. Penelitian ini juga menggunakan algoritma honey bee mating optimization yang belum pernah diterapkan pada kasus penjadwalan sepak bola.

Sehingga sistem ini akan memberikan hasil berupa penjadwalan untuk kompetisi Liga PSN Ngada pada fase 1, setelah dilakukan proses perhitungan menggunakan algoritma honey bee mating optimization dengan inputan parameter dari user. Hasil dari sistem ini berupa penjadwalan dengan jumlah kesalahan paling sedikit yang dapat menjadi solusi dalam penentuan jadwal kompetisi liga PSN Ngada.

\section{Metode Penelitian}

\subsection{Honey Bee Mating Optimization}

Suatu koloni lebah biasanya berjumlah kurang lebih 10.000 sampa 60.000 lebah pekerja dan lebah jantan, dalam koloni ini lebah jantan mengelilingi satu ekor lebah yang menjadi ratu dalam koloni tersebut. Seekor ratu lebah bisa hidup sampai dengan 6 tahun, tugas ratu lebah adalah menjadi lebah untuk bertelur. Berbanding terbalik dengan lebah jantan dan lebah pekerja yang memiliki usia tidak sampai dengan 6 tahun.

Ratu lebah akan mendapatkan sel telur setelah melakukan pembuahan dengan lebah jantan. Setelah melakukan perkawinan dengan ratu, lebah jantan akan mati dan lebah pekerja akan merawat dan memberi makan kepada bayi lebah hasil pembuahan sebelumnya. Pada kumpulan bayi lebah tersebut jika ada yang memiliki unsur genetic yang lebih baik atau sama dengan ratu, maka bayi lebah tersebut akan dipersiapkan untuk menjadi ratu selanjutnya dalam koloni tersebut.

Ketika dalam proses perkawinan ratu lebah akan terbang menjauh dari koloni lebah dan diikuti oleh lebah jantan. Selama proses terbangnya ratu, ratu akan melakukan tarian yang bertujuan memberitahukan bahwa ratu siap untuk dibuahi. Lebah jantan yang dapat mengikuti kecepatan ratu akan melakukan proses perkawinan dengan ratu diudara. Selama proses perkawinan sel sperma lebah jantan akan disimpan didalam spermatheca ratu lebah, dan proses perkawinan akan berakhir ketika jumlah spermathecal ratu penuh atau ratu kelelahan saat terbang. Nantinya setiap sperma didalam spermathecal ratu akan diambil untuk dibuahi. Dan bayi ratu yang lahir akan dirawat dan ditentukan apakah layak untuk menggantikan ratu lebah [7]. Dari penjelasan sebelumnya dapat ditentukan alur algoritmanya menjadi seperti berikut [7]:

1. Proses inisialisasi genotype yang dimiliki ratu lebah dan lebah jantan dalam populasi.

2. Proses perkawinan ratu lebah dan lebah jantan diudara, dimana ratu lebah akan menyimpan sperma lebah jantan kedalam spermathecal ratu. Sperma yang ada dalam spermathecal ratu itu akan diambil untuk dilakukan proses pembuahan.

3. Proses pembuahan untuk menghasilkan bayi lebah baru dilakukan secara silang (crossover) antara sel telur ratu dan sel sperma dari ratu lebah.

4. Setelah individu baru lahir, lebah pekerja akan melakukan pencarian ke setiap individu baru, dan jika memungkinkanlakukan proses mutasi terhadap bayi lebah dengan menggunakan royal jelly yang dimiliki lebah pekerja sebagai katalis.

5. Jika terdapat bayi lebah yang lebih baik dari ratu maka bayi lebah tersebut yang akan menjadi ratu. Setelah itu lakukan kembali proses perkawinan untuk mendapatkan bayi lebah baru.

REPOSITOR, Vol. 2, No. 3, Maret 2020: 297-304 
Secara garis besar algoritma honey bee mating optimization dimulai dengan insialisasi genotype, flight mating, proses pembuahan, mutasi bayi lebah, pemilihan ratu baru dan iterasi(looping), seperti yang dilihat di Gambar 1.

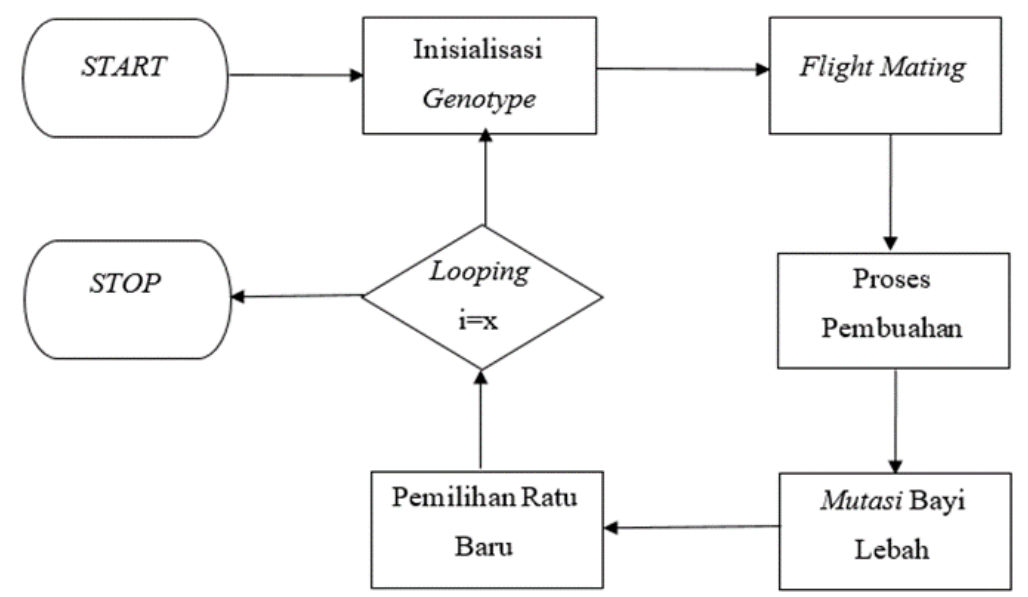

Gambar 1. Flowchart Algoritma Honey bee Mating Optimization

a. Inisialisasi Genotype

Pada Persamaan 1, tahap ini sekumpulan individu lebah akan dikumpulkan, individu lebah jantan ini ada yang memiliki nilai yang baik tetapi juga ada yang memiliki kualitas rendah. Dari individu ini akan terjadinya proses perkawinan dengan ratu, biasanya individu terbaik yang akan diambil untuk dilakukan perkawinan dengan sang ratu dan juga ratu lebah akan dipilih dari kumpulan lebah ini, ratu yang dipilih merupakan lebah dengan kualitas terbaik didalam populasi [7].

$$
D=[D 1, D 2, D 3, \ldots \ldots, D m]
$$

\section{b. Flight Mating}

Tahap ini setiap lebah jantan yang dipilih tadi akan menyimpan atau memasukan sel sperma mereka kedalam spermatheca milik si ratu, proses Persamaan 2 ini akan terus berlangsung hingga spermatheca ratu penuh atau sang ratu kelelahan. Pada proses flight mating, spermatheca ratu memiliki variabel $\mathrm{n}$, variabel ini adalah nilai yang dapat ditampung spermatheca sang ratu. Nilai dari $\mathrm{n}$ sendiri dapat ditentukan oleh user atau pengguna, nilai dari variabel $\mathrm{n}$ tidak boleh melebihi individu lebah jantan yang melakukan perkawinan dengan sang ratu [7].

$$
\text { Sperm }=[\mathrm{Sp} 1, \mathrm{Sp} 2, \mathrm{Sp} 3, \ldots, \mathrm{Spn}]
$$

\section{c. Proses Pembuahan/Crossover}

Proses ini lebih dikenal dengan proses perkawinan silang atau crossover, dimana sel-sel lebah jantan yang ada di spermatheca ratu kemudian dipilih secara acak dan dikawinkan dengan sel telur ratu atau sering disebut crossover. Proses Persamaan 3 ini menggabungkan gen dari ratu lebah dan gen dari lebah jantan [8].

$$
\text { Broodi }=(\text { Brood 1/J,Brood 1/J,Brood 1/J, ...,Brood i/J })
$$

\section{d. Mutasi}

Setiap individu yang baru yang merupakan hasil dari pembuahan ratu lebah kemudian akan digenerate untuk dapat menghasilkan / meningkatkan kualitas individu yang lebih baik. Proses Gambar 3 ini merupakan proses dimana merubah salah satu gen yang berada pada nilai individu tersebut.

Mutasi berfungsi agar individu baru tetap memiliki variasi populasi, tapi proses melakukan mutasi sebaiknya tidak terlalu banyak, yang dapat menghilangkan atau mengurangi kemiripan anak dan induknya. Dan juga sebaiknya tidak terlalu kecil, karena gen yang kurang baik tidak akan ikut terevaluasi [9]. 


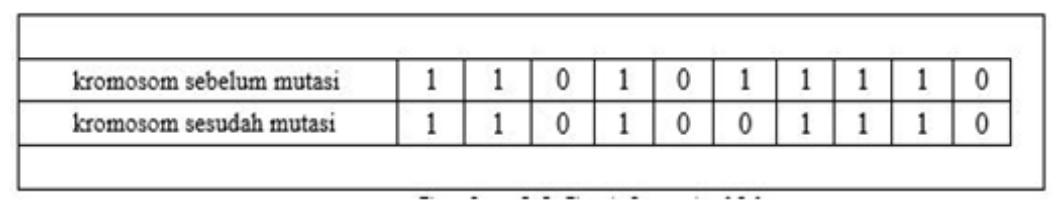

Gambar 3. Contoh Proses Mutasi

e. Pemilihan Ratu Baru

Pemilihan ratu baru dilakukan dengan cara membandingkan nilai fitness dari ratu lebah dan individu baru hasil pembuahan dan mutasi. Jika pada Persamaan 4, nilai fitness dari individu baru lebih besar dari nilai fitness ratu lebah maka posisi ratu lebah akan diganti dengan individu baru, tetapi jika nilai fitness dari ratu lebah lebih besar dari individu baru maka ratu lebah akan tetap di posisi ratu dan akan dilakukan perulangan hingga mencapai batas yang sudah ditentukan user [7].

$$
F=\frac{1}{1+((x 1)+(x 2)+(x 3)+\cdots x+(x n))}
$$

\section{f. Looping/lterasi}

Pada tahap looping/iterasi ketika penjadwalan dan penentuan ratu telah diproses maka akan diulang kembali menuju proses penentuan lebah yang akan melakukan perkawinan dengan ratu, proses looping akan berakhir sesuai dengan inputan dari user.

Data yang digunakan pada penelitian berupa, tanggal kompetisi dilaksanakan, nama tim yang bertanding, asal daerah setiap tim, batasan/constraint untuk sistem, dan informasi lainnya yang digunakan pada sistem. Data diperoleh dari panitia kompetisi Liga PSN Ngada dan untuk batasan/constraint berasal dari beberapa panitia, manager, pelatih, pemain dan supporter. Untuk aturan yang digunakan pada sistem ini terdapat 7 constraint, antara lain:

1. Setiap tim bermain sebanyak 9 kali.

2. Dalam 1 minggu terdapat 5 pertandingan.

3. Setiap tim bermain 1 kali dalam 1 minggu.

4. Tidak ada 2 pertandingan diwaktu yang sama.

5. Setiap tim bertanding satu kali dengan tim lainnya.

6. Sesama tim peringkat A bermain pada pukul 16.00 WITA.

7. Sesama tim yang berlokasi jauh dari stadion bermain pada pukul 14.00 WITA.

Batasan pada sistem ini akan menjadi faktor perhitungan nilai fitness yang menunjukan kualitas dari jadwal yang dibentuk dengan algoritma honey bee mating optimization. Semakin baik nilai fitnessnya maka semakin baik juga penjadwalan yang dibentuk. Untuk perhitungan setiap kesalahan pada constraint akan dibagi atas 2, hard constraint merupakan pelanggaran yang tidak boleh dilanggar dan soft constraint yang dapat dilanggar tetapi dengan batasan tertentu(4).

Untuk perhitungan hard constraint dan soft constraint tergantung berdasarkan kebutuhan pada sistem, pada penelitian ini untuk setiap kesalah hard constraint akan dihitung 1 dan untuk setiap pelanggaran soft constraint akan dihitung 0.5. jumlah dari semua total kesalahan akan ditambah 1 dan akan dibagi dengan angka, hasil dari perhitungan yang akan menjadi nilai fitness [10]. antara lain:

Pengujian pada penelitian ini akan diuji untuk 4 parameter yang diinputkan oleh user

1. Menentukan Jumlah Iterasi

Jumlah iterasi akan diuji untuk mencari berapa maksimum iterasi yang dapat memberikan hasil penjadwalan yang baik. Jumlah iterasi yang tepat sebaiknya tidak terlalu besar karena dapat memakan waktu yang lama atau tidak terlalu kecil karena kombinasi yang terbentuk akan berkurang.

2. Menentukan Populasi/Individu yang Dibentuk.

Menentukan jumlah populasi atau individu adalah mencari jumlah individu atau solusi penjadwalan yang dibangkitkan. Solusi jadwal ini yang akan menjadi ratu dan individu lebah jantan yang akan melakukan proses perkawinan dengan ratu. Jumlah individu juga sebaiknya tidak terlalu sedikit karena variasi dari individu akan sedikit, tetapi tidak terlalu besar karena akan memakan waktu yang banyak. 
3. Menentukan Kapasitas Spermatheca.

Pengujian pada kapasitas spermatheca adalah menguji berapa jumlah lebah jantan yang akan melakukan perkawinan dengan ratu lebah. Jumlah spermatheca akan mempengaruhi jumlah variasi bayi lebah hasi dari pembuahan ratu lebah.

4. Menentukan Nilai Rasio Mutasi

Nillai rasio mutasi merupakan nilai yang diterapkan oleh user, sistem akan mengacak nilai dari 0-1, jika nilai mutasi lebih besar dari nilai yang dirandom maka sistem akan menukarkan beberapa nilai pada gen lebah tersebut, sebaiknya jumlah gen yang ditukar tidak terlalu banyak dan juga tidak terlalu sedikit.

\section{Hasil Penelitian dan Pembahasan}

Pengujian pada Tabel 1 penelitian ini dilakukan dengan mambandingkan hasil yang nilai parameter telah diinputkan oleh pengguna sistem. Parameter yang dilakukan pengujian antara lain, jumlah iterasi, jumlah individu, kapasitas spermatheca, dan nilai rasio mutase.

Tabel 1. Nilai Parameter Pengujian

\begin{tabular}{cccc}
\hline No & Parameter & Min. Value & Max. Value \\
\hline 1. & Maksimum Iterasi & 10 & 1000 \\
2. & Jumlah Individu & 30 & 900 \\
3. & Kapasitas Spermatheca & 10 & 50 \\
4. & Nilai Rasio Mutasi & 0.1 & 0.7 \\
\hline
\end{tabular}

\subsection{Pengujian Jumlah Maksimum Iterasi}

Pada jumlah iterasi setelah dilakukan pengujian dengan 5 kali percobaan pada rentang nilai maksimum iterasi 10-1000 menunjukan bahwa nilai penjadwalan paling baik adalah 900 iterasi dengan rata-rata nilai fitness 0.48 dengan waktu proses 205.78 detik, dapat dilihat pada Tabel 2 dan Tabel 3.

Tabel 2. Hasil Pengujian Jumlah Iterasi

\begin{tabular}{ccccccc}
\hline \multirow{2}{*}{ Percobaan Ke - } & \multicolumn{6}{c}{ Hasil Pengujian Berdasarkan Jumlah Nilai Iterasi Maksimum } \\
\cline { 2 - 7 } & 10 & 300 & 500 & 700 & 900 & 1000 \\
\hline 1 & 0.1538 & 0.3333 & 0.3333 & 0.2857 & 0.5 & 0.4 \\
2 & 0.1538 & 0.4 & 0.3333 & 0.3333 & 0.5 & 0.5 \\
3 & 0.2000 & 0.2857 & 0.2222 & 0.6667 & 0.3333 & 0.5 \\
4 & 0.1818 & 0.5 & 0.2500 & 0.4 & 0.4 & 0.2500 \\
5 & 0.1667 & 0.6667 & 0.5 & 0.5 & 0.6667 & 0.4 \\
\hline Rata-Rata & 0.1712 & 0.4371 & 0.3277 & 0.4371 & 0.48 & 0.4100 \\
\hline
\end{tabular}

Tabel 3. Hasil Pengujian Waktu Iterasi

\begin{tabular}{ccccccc}
\hline \multirow{2}{*}{ Percobaan Ke -} & \multicolumn{6}{c}{ Hasil Waktu Pengujian } \\
\cline { 2 - 7 } & 10 & 300 & 500 & 700 & 900 & 1000 \\
\hline 1 & 2.3260 & 68.16 & 114.12 & 158.16 & 204.73 & 233.01 \\
2 & 2.3008 & 69.16 & 116.89 & 159.20 & 206.31 & 233.73 \\
3 & 2.2813 & 69.78 & 114.37 & 158.56 & 205.39 & 233.61 \\
4 & 2.2949 & 69.03 & 115.68 & 158.94 & 206.82 & 233.05 \\
5 & 2.2620 & 69.87 & 116.96 & 159.21 & 205.65 & 234.51 \\
\hline Rata-Rata & 2.398 & 69.32 & 115.6 & 158.53 & 205.78 & 233.14 \\
\hline
\end{tabular}

Menunjukkan bahwa nilai penjadwalan terbaik terdapat pada iterasi ke 900 , tetapi untuk penjadwalan optimal iterasi ke 300 dipilih karena memiliki nilai rata-rata fitness yang cukup 0.4371 dan waktu yang lebih cepat dari iterasi ke 900 dengan 69.32 detik.

\subsection{Pengujian Jumlah Individu Awal}

Pada jumlah individu setelah dilakukan 5 kali percobaan pada rentang nilai 30-900 individu hasilnya menunjukan bahwa nilai individu terbaik pada 900 individu dengan nilai rata-rata fitness 0.6 dan membutuhkan waktu 3371.66 detik yang dapat dilihat pada Tabel 4 dan Tabel 5. 


\begin{tabular}{|c|c|c|c|c|c|}
\hline \multicolumn{6}{|c|}{ Tabel 4 Hasil Pengujian Jumlah Individu } \\
\hline \multirow[t]{2}{*}{ Percobaan Ke - } & \multicolumn{5}{|c|}{$\begin{array}{l}\text { Hasil Pengujian Berdasarkan Jumlah Individu yang } \\
\text { Dibangkitkan }\end{array}$} \\
\hline & 30 & 300 & 400 & 700 & 900 \\
\hline 1 & 0.4 & 0.4 & 0.6667 & 0.4 & 1 \\
\hline 2 & 0.2857 & 0.3333 & 0.4 & 0.5 & 0.6667 \\
\hline 3 & 0.2500 & 0.5 & 0.4 & 0.3333 & 0.3333 \\
\hline 4 & 0.5 & 0.6667 & 0.6667 & 0.6667 & 0.5 \\
\hline 5 & 0.3333 & 0.6667 & 0.4371 & 0.6667 & 0.5 \\
\hline Rata-Rata & 0.3738 & 0.5134 & 0.5141 & 0.5253 & 0.6 \\
\hline \multicolumn{6}{|c|}{ Tabel 5 Hasil Pengujian Waktu Jumlah Individu } \\
\hline Percobaan Ke - & \multirow{2}{*}{\multicolumn{5}{|c|}{ 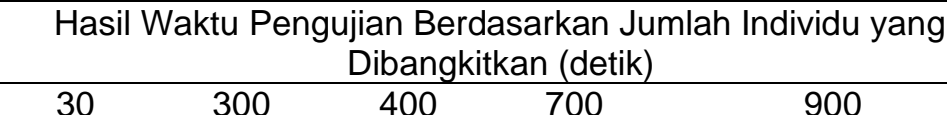 }} \\
\hline & & & & & \\
\hline 1 & 115.44 & 1352.28 & 1879.12 & 2333.51 & 3404.73 \\
\hline 2 & 118.05 & 1376.70 & 1882.52 & 2242.87 & 3256.31 \\
\hline 3 & 116.41 & 1382.84 & 1854.37 & 2242.87 & 3429.39 \\
\hline 4 & 110.88 & 1363.78 & 1868.15 & 2218.74 & 3377.82 \\
\hline 5 & 112.69 & 1352.53 & 1896.26 & 2558.94 & 3122.65 \\
\hline Rata-Rata & 114.69 & 1365.62 & 1875.33 & 2335.75 & 3371.66 \\
\hline
\end{tabular}

Hasilnya menunjukan bahwa 900 individu memiliki nilai terbaik tetapi dalam pemilihan selanjutnya jumlah individu ke 300 dipilih sebagai nilai paling optimal karenamampu memberikan hasil yang baik dengan rata-rata fitness 0.5134 dan waktu yang lebih cepat dari 900 individu yaitu 1365.62 detik.

\subsection{Pengujian Kapasitas Spermatheca}

Pada jumlah kapasitas spermatheca setelah dilakukan 5 kali percobaan dengan rentang nilai kapasitas spermatheca 10-50 spermatheca, hasil penjadwalan paling optimal terdapat pada kapasitas spermathecal sebesar 40 dengan nilai rata-rata fitness 0.6133 dan waktu yang dibutuhkan 1477.33 detik, dapat dilihat pada Tabel 6 dan Tabel 7.

Hasill pengujian menunjukan bahwa kapasiitas spermatheca 40 memiliki nilai rata-rata fitness 0.6133 menjadi nilai yang dipilih karena memiliki nilai paling tinggi dan selisih waktu lebih baik dibandingkan kapasitas spermatheca 50 .

Tabel 6. Hasil Pengujian Jumlah Spermatheca

\begin{tabular}{|c|c|c|c|c|c|}
\hline \multirow{2}{*}{ Percobaan Ke - } & \multicolumn{5}{|c|}{ Hasil Pengujian Berdasarkan Jumlah Spermatheca Ratu } \\
\hline & 10 & 20 & 30 & 40 & 50 \\
\hline 1 & 0.4 & 0.5 & 0.5 & 0.4 & 1 \\
\hline 2 & 0.6667 & 1 & 0.6667 & 0.5 & 0.5 \\
\hline 3 & 0.5 & 0.4 & 0.5 & 0.5 & 0.4 \\
\hline 4 & 0.5 & 0.5 & 0.5 & 1 & 0.4 \\
\hline 5 & 0.4 & 0.5 & 0.4 & 0.6667 & 0.6667 \\
\hline Rata-Rata & 0.4934 & 0.58 & 0.5133 & 0.6133 & 0.5933 \\
\hline
\end{tabular}

Tabel 7. Hasil Pengujian Waktu Jumlah Spermatheca

\begin{tabular}{cccccc}
\hline \multirow{2}{*}{$\begin{array}{c}\text { Percobaan } \\
\text { Ke }-\end{array}$} & \multicolumn{5}{c}{ Hasil Waktu Pengujian $\begin{array}{c}\text { Berdasarkan Maksimum Spermatheca } \\
\text { Ratu (detik) }\end{array}$} \\
\cline { 2 - 6 } & 10 & 20 & 30 & 40 & 50 \\
\hline 1 & 1215.54 & 1352.32 & 1458.28 & 1482.54 & 1609.12 \\
2 & 1238.27 & 1394.37 & 1492.70 & 1496.34 & 1612.52 \\
3 & 1226.62 & 1363.38 & 1497.84 & 1482.33 & 1604.37 \\
4 & 1230.03 & 1302.09 & 1488.78 & 1473.22 & 1595.68 \\
5 & 1240.24 & 1372.64 & 1495.53 & 1452.25 & 1616.96 \\
\hline Rata-Rata & 1222.94 & 1356.96 & 1486.62 & 1477.33 & 1607.73 \\
\hline
\end{tabular}

REPOSITOR, Vol. 2, No. 3, Maret 2020: 297-304 


\subsection{Pengujian Nilai Rasio Mutasi}

Pada pengujian nilai rasio mutasi setelah dilakukan pengujian sebanyak 5 kali percobaan dengan rentang nilai 0,1 sampai 0.7 , dimana nilai rasio mutase paling baik terdapat pada nilai 0.6 dengan rata-rata 0.7334 dengan waktu yang 1461.51 detik sedikit lebiih baik dengan nilai mutase 0.7. Hasil perhitungan dapat dilihat pada Tabel 8 dan Tabel 9.

Tabel 8. Hasil Pengujian Nilai Rasio Mutasi

\begin{tabular}{cccccc}
\hline Percobaan & \multicolumn{5}{c}{ Hasil Pengujian Berdasarkan Nilai Rasio Mutasi } \\
\cline { 2 - 6 } Ke - & 0.1 & 0.4 & 0.5 & 0.6 & 0.7 \\
\hline 1 & 0.4 & 0.4 & 1 & 0.6667 & 0.5 \\
2 & 0.6667 & 0.6667 & 0.6667 & 0.5 & 0.6667 \\
3 & 0.5 & 0.5 & 0.5 & 1 & 0.4 \\
4 & 0.4 & 1 & 0.5 & 1 & 1 \\
5 & 0.3333 & 0.6667 & 0.4 & 0.5 & 1 \\
\hline Rata-Rata & 0.46 & 0.6466 & 0.6133 & 0.7334 & 0.7134 \\
\hline
\end{tabular}

Tabel 9. Hasil Pengujian Waktu Nilai Rasio Mutasi

\begin{tabular}{cccccc}
\hline Percobaan & \multicolumn{5}{c}{ Hasil Waktu Pengujian Berdasarkan Nilai Rasio Mutasi } \\
\cline { 2 - 6 } Ke - & 0.1 & 0.4 & 0.5 & 0.6 & 0.7 \\
\hline 1 & 1498.54 & 1425.52 & 1461.69 & 1465.64 & 1483.27 \\
2 & 1428.27 & 1437.22 & 1459.86 & 1423.46 & 1494.31 \\
3 & 1478.62 & 1488.8 & 1409.13 & 1444.44 & 1474.66 \\
4 & 1463.30 & 1469.43 & 1421.25 & 1485.73 & 1430.49 \\
5 & 1441.24 & 1448.45 & 1493.21 & 1488.3 & 1419.25 \\
\hline Rata-Rata & 1461.95 & 1477.33 & 1453.88 & 1461.51 & 1473.59 \\
\hline
\end{tabular}

Nilai parameter yang menjadi kombinasi akhir dari pengujian ini yang memberikan penjadwalan paling optimal ditentukan berdasarkan nilai terpilih pada setiap poin pengajian yaitu, jumlah iterasi sebesar 300 iterasi, jumlah individu awal sebesar 300 individu, kapasitas spermatheca sebesar 40 dan nilai rasio mutasi sebesar 0.6 , yang memberikan hasil nilai fitness dengan rata-rata 0.7334 dan waktu proses 1461.51 detik.

\section{Kesimpulan}

Penelitian ini telah menghasilkan sistem penjadwalan kompetisi sepak bola liga PSN Ngada dengan menggunakan algoritma honey bee mating optimization. Penjadwalan yang terbentuk merupakan 1 penjadwalan kompetisi secara lengkap yang diikuti oleh 10 tim. Pengujian pada penelitian ini dilakukan dengan munguji parameter yang diinputkan pengguna yaitu, jumlah iterasi, individu awal, kapasitas spermathecal dan rasio mutasi. Setiap pengujian akan menghasilkan perbedaan hasil bergantung dengan jumlah individu yang dibangkitkan yang menjadi solusi penjadwalan. Namun dengan jumlah parameter yang tepat dapat mempersempit kemungkinan untuk mendapatkan kombinasi penjadwalan yang memiliki nilai yang paling optimal dengan sedikit melanggar kesalahan pada sistem yang telah ditetapkan sebelumnya.

\section{Daftar Notasi}

Notasi yang digunakan dalam pehitungan algoritma honey bee mating optimization pada penjadwalan Liga PSN Ngada antara lain;

$\mathrm{D}=$ individu lebah jantan

Sp-i = sel sperma ke-i lebah jantan

Brood = Individu baru yang dihasilkan

$\mathrm{x}=$ nilai dari individu pada nilai constraint

\section{Referensi}

[1] William. Penjadwalan Pertandingan Liga Dengan Algoritma Greedy. 2008.

[2] Gunardi W. Penjadwalan Kompetisi Sepak Bola Menggunakan Metode Erdos-Renyi De KNN Dan Rule-Based System Untuk Meminimalkan Biaya Operasional Klub. Universitas Islam Negeri (UIN) Maulana Malik Ibrahim Malang; 2013. 
[3] Hijriana N. Penerapan Metode Algoritma Genetika Untuk Permasalahan Penjadwalan Perawat ( Nurse Schedulling Problem ). Info Tek. 2015;16(1):61-74.

[4] Djamal EC, Komarudin A. Optimalisasi Penjadwalan Babak Penyisihan Pertandingan Sepak Bola Liga Mahasiswa Jawa Barat Menggunakan Algoritma Genetika. 2017;8(August):1-6.

[5] Sabar NR, Ayob M, Kendall G, Qu R. Discrete Optimization A honey-bee mating optimization algorithm for educational timetabling problems. Eur J Oper Res [Internet]. 2012;216(3):53343. Available from: http://dx.doi.org/10.1016/j.ejor.2011.08.006

[6] Etp-hbmo O, Sabar NR, Ayob M, Kendall G. Solving Examination Timetabling Problems using Honey-bee Mating. 2009;(August):10-2. Available from: https://www.researchgate.net/publication/258222179_Solving_Examination_Timetabling_P roblems_using_Honey-bee_Mating_Optimization_ETP-HBMO

[7] Azhar Y, Kholimi AS. Metode Hybrid Maximum Tsallis Entropy Dan Honey Bee Mating Optimization Untuk Pencarian Multilevel Threshold Pada Citra Grayscale. 2012;10:32-7.

[8] Nugroho AK. Penerapan Algoritma Genetika Untuk Menyelesaikan Permasalahan Penjadwalan Dosen Dengan Fuzzy Arief. Zeitschrift fur Wundheilung. 2011;16(SUP_A):724.

[9] Muliadi. Pemodelan Algoritma Genetika Pada Sistem Penjadwalan Perkuliahan Prodi Ilmu Komputer Universitas Lambungmangkurat. Kumpul J Ilmu Komput. 2014;01(01):67-78.

[10] Baradaran Tavakoli H, Mozafari B, Soleymani S. Short-term hydrothermal scheduling via honey-bee mating optimization algorithm. Asia-Pacific Power Energy Eng Conf APPEEC. 2012; 